\title{
Durability of tissue valves: Only time will tell?
}

\author{
Torsten Doenst, MD, PhD
}

\author{
From the Department of Cardiothoracic Surgery, Jena University Hospital, Friedrich-Schiller-University of Jena, \\ Jena, Germany. \\ Disclosures: Author has nothing to disclose with regard to commercial support. \\ Received for publication May 31, 2017; accepted for publication June 5, 2017; available ahead of print June 29, \\ 2017. \\ Address for reprints: Torsten Doenst, MD, PhD, Department of Cardiothoracic Surgery, Friedrich-Schiller- \\ University of Jena, Am Klinikum 1, 07747 Jena, Germany (E-mail: doenst@med.uni-jena.de). \\ J Thorac Cardiovasc Surg 2017;154:1243-4 \\ $0022-5223 / \$ 36.00$ \\ Copyright (c) 2017 by The American Association for Thoracic Surgery \\ http://dx.doi.org/10.1016/j.jtcvs.2017.06.007
}

Durability has been one of the 2 most important cornerstones for widespread acceptance of a tissue valve. The other one is hemodynamic performance. Newergeneration tissue valves have been associated with improved durability, ${ }^{1}$ a perception that has contributed to the ever-growing use of tissue valves for aortic valve replacement independently of age, with the use of mechanical valves becoming almost negligible. ${ }^{2}$ Thus, mechanisms of tissue valve failure should be important.

However, current practice often counteracts current evidence. For instance, transcatheter tissue valves increasingly are implanted in patients with lower risk (and therefore longer life expectancy). ${ }^{3}$ Their long-term durability is currently unknown. The increasing use of tissue valves for conventional aortic valve replacement is accompanied by growing evidence for the superiority of mechanical valves regarding hemodynamics and survival. $^{4}$ The often quoted valve-in-valve option, which also has been used by Kalra and colleagues ${ }^{5}$ in this issue of the Journal, to treat 2 Trifecta (St Jude Medical, Saint Paul, Minn) failures may not be the answer to all durability questions, at least in $2017 .^{6}$ Finally, valves with the best documented durability may not be the newest ones.

Because optimal hemodynamics may be associated with better results (possibly including survival and durability), the Trifecta filled a gap for tissue valves, because its new design and sizing strategy resulted in superior hemodynamics in almost all published reports. ${ }^{8,9}$ In addition, durability in in vitro accelerated wear testings has been remarkable (https://www.sjm.com/ /media/galaxy/hcp/ featured-products/structural-heart/trifecta-gt/ide10cvd1858 en1-trifecta-white-paper-a4-ous.pdf). Thus, reports such as the one by Kalra and colleagues, ${ }^{5}$ demonstrating a new and early failure mechanism, should raise significant attention in the community, despite the discrepancy of evidence and practice.

Kalra and colleagues ${ }^{5}$ demonstrate that 8 of approximately 700 Trifecta valves failed within a mean of 32 months as the result of pannus formation on the inside of the

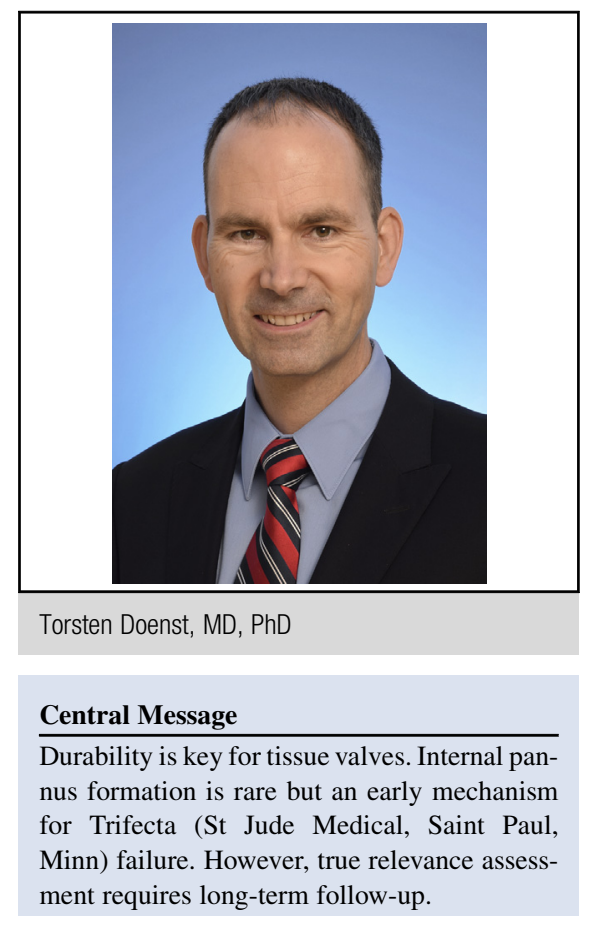

See Article page 1235 .

prostheses and leaflet calcification around the posts. This specific mechanism is unusual because pannus formation has been considered a characteristic mechanism for late failures of pericardial valves. ${ }^{10}$ It also cannot be addressed easily by valve modifications because the cause is not clear. For other reported mechanisms (ie, leaflet tears, possibly the result of mechanical stress during implantation) and reasons, the company modified the design and valve holder for the new Trifecta GT model (https://www.sjm.com/ /media/ galaxy/hcp/featured-products/structural-heart/trifecta-gt/ ide10cvd1858en1-trifecta-white-paper-a4-ous.pdf).

Currently, the number of failures in the study by Kalra and colleagues ${ }^{5}$ still seems acceptably small, with approximately $1 \%$ of all implants (although the number may be higher for lack of complete echocardiographic follow-up). All other reports have presented excellent rates for freedom from structural valve deterioration, 8,9 thus far. Therefore, it seems safe to continue using the Trifecta (specifically for its hemodynamic properties). However, careful follow-up of all tissue valves seems to be a "must." In the end, one (possibly unpleasant) principle applies to the durability of all new tissue valves (conventional or transcatheter): "Only time will tell." 


\section{References}

1. Chikwe J, Filsoufi F. Durability of tissue valves. Semin Thorac Cardiovasc Surg. 2011;23:18-23.

2. Beckmann A, Funkat AK, Lewandowski J, Frie M, Ernst M, Hekmat K, et al. German Heart Surgery Report 2015: the annual updated registry of the German Society for Thoracic and Cardiovascular Surgery. Thorac Cardiovasc Surg. 2016; 64:462-74.

3. Nishimura RA, Otto CM, Bonow RO, Carabello BA, Erwin JP III, Fleisher LA, et al. 2017 AHA/ACC Focused Update of the 2014 AHA/ACC Guideline for the Management of Patients With Valvular Heart Disease: A Report of the American College of Cardiology/American Heart Association Task Force on Clinical Practice Guidelines. Circulation. March 15, 2017 [Epub ahead of print].

4. Brown ML, Schaff HV, Lahr BD, Mullany CJ, Sundt TM, Dearani JA, et al. Aortic valve replacement in patients aged 50 to 70 years: improved outcome with mechanical versus biologic prostheses. J Thorac Cardiovasc Surg. 2008; $135: 878-84$

5. Kalra A, Rehman H, Ramchandani M, Barker CM, Lawrie GM, Reul RM, et al. Early Trifecta valve failure: report of a cluster of cases from a tertiary care referral center. J Thorac Cardiovasc Surg. 2017;154:1235-40.

6. Raval J, Nagaraja V, Eslick GD, Denniss AR. Transcatheter valve-in-valve implantation: a systematic review of literature. Heart Lung Circ. 2014;23:1020-8.

7. Myken PS, Bech-Hansen OA. 20-year experience of 1712 patients with the Biocor porcine bioprosthesis. J Thorac Cardiovasc Surg. 2009;137:76-81.

8. Goldman S, Cheung A, Bavaria JE, Petracek MR, Groh MA, Schaff HV. Midterm, multicenter clinical and hemodynamic results for the Trifecta aortic pericardial valve. J Thorac Cardiovasc Surg. 2017;153:561-9.e562.

9. Lehmann S, Meyer A, Schroeter T, Uhlemann M, Fischer J, Leontyev S, et al. Midterm durability and hemodynamic performance of a third-generation bovine pericardial prosthetic aortic valve: the Leipzig experience. Ann Thorac Surg. 2017;103:1933-9.

10. Grunkemeier GL, Furnary AP, Wu Y, Wang L, Starr A. Durability of pericardial versus porcine bioprosthetic heart valves. J Thorac Cardiovasc Surg. 2012;144:1381-6. 